\title{
Influence of Surface Finishing on High-Temperature Oxidation of AISI Type 444 Ferritic Stainless Steel Used in SOFC Stacks
}

\author{
Valeria Bongiorno $^{1} \cdot$ Paolo Piccardo $^{1} \cdot$ Simone Anelli $^{1} \cdot$ Roberto Spotorno $^{1}$
}

Received: 8 September 2016/Revised: 27 December 2016/Published online: 16 February 2017

(C) The Chinese Society for Metals and Springer-Verlag Berlin Heidelberg 2017

\begin{abstract}
This research is focused on the study of the samples, approximatively $15 \times 30 \mathrm{~mm}^{2}$ sized, that were mechanically cut from two sheets (0.4 and $0.2 \mathrm{~mm}$ thick, respectively) of AISI 444 Type ferritic stainless steel (FSS) (DIN 1.4521, Eu designation X2CrMoTi18-2); this material was in the 'as-rolled' state. Part of these specimens were treated superficially on one side using abrasive $\mathrm{SiC}$ papers with different average grit sizes (i.e., 46.2, 30.2, $18.3 \mu \mathrm{m}$ ) and diamond suspension (up to $1 \mu \mathrm{m}$ ) in order to obtain various surface roughness. Both the 'as-rolled' and superficially treated samples were then aged in a muffle furnace in static air according to a thermal cycle corresponding to the curing phase of an experimental glass used as sealing in the solid oxide fuel cell stacks. After aging, the chemical compositions and morphological peculiarities of the scale formed depending on the thickness of the samples and their surface state were studied by scanning electron microscopy, energy-dispersive spectroscopy, micro-Raman spectroscopy, bright field light optical microscopy. The obtained results show that all scales formed consist of an inner $\mathrm{Cr}_{2} \mathrm{O}_{3}$ subscale and an outer $(\mathrm{Mn}, \mathrm{Cr})_{3} \mathrm{O}_{4}$ spinel layer; the relationship between FSS grain size and scale microstructural features is consistent on the samples with mirror-like surface only; the scale thicknesses on $\mathrm{SiC}$ grinded samples are comparable; the scales covering the 'as-rolled' surfaces are morphologically similar to those grown on the surfaces finished with the 30.2 and $18.3 \mu \mathrm{m} \mathrm{SiC} \mathrm{papers,} \mathrm{and}$ their thicknesses show an intermediate situation between the abraded and the mirror-like specimens. The last described characteristics depend mainly on the surface and microstructural peculiarities resulting from the rolling process.
\end{abstract}

KEY WORDS: AISI Type 444; SOFC stacks; Surface roughness; Microstructure; Surface finishing; Hightemperature oxidation

Available online at http://link.springer.com/journal/40195

Valeria Bongiorno

valeria.bongiorno@gmail.com

Paolo Piccardo

paolo.piccardo@unige.it

Simone Anelli

anelli.simone@outlook.com

Roberto Spotorno

roberto.spotorno@edu.unige.it

1 Laboratorio di Metallurgia e Materiali - Dipartimento di Chimica e Chimica Industriale (LMM-DCCI), Università degli Studi di Genova, Via Dodecaneso 31, 16146 Genoa, Italy

\section{Introduction}

Intermediate temperature $\left(600-800{ }^{\circ} \mathrm{C}\right)$ solid oxide fuel cells (IT-SOFCs) are alternative systems for the direct conversion of chemical energy, stored within the fuels containing hydrogen, into electrical energy, heat and water with a low environmental impact and high efficiency [1-8].

Single SOFC produces around $1-\mathrm{V}$ open circuit potential (OCV) and, in order to generate a reasonable voltage, SOFCs are arranged together as a stack, with interconnects joining the anodes and cathodes of adjacent units $[3,4,9,10]$.

For more than a decade, ferritic stainless steels (FSSs) have been considered the best candidates to manufacture 
interconnects for stacking IT-SOFCs since they exhibit adequate prerequisites: similar thermal expansion coefficient (TEC) to the other ceramic parts of the fuel cell, excellent formability, affordable cost and the formation of a comparatively conductive and protective $\mathrm{Cr}_{2} \mathrm{O}_{3}$ scale in the presence of oxidant (this is the case of chromia-former steels containing over $15 \mathrm{wt} \% \mathrm{Cr}$ ) [9, 11-15].

Nevertheless, under SOFC operative conditions and a planned service of 40,000 h they show an unacceptably low oxidation resistance; the formation of volatile $\mathrm{Cr}(\mathrm{VI})$ containing species [e.g., $\mathrm{CrO}_{3}$ and $\mathrm{Cr}(\mathrm{OH})_{2} \mathrm{O}_{2}$ ] from oxidation of chromia in the interconnect; and their reduction at the cathode three-phase boundary (TPB) to form $\mathrm{Cr}_{2} \mathrm{O}_{3}$ $[14,16,17]$. $\mathrm{Cr}$ poisoning represents one of the main drawbacks to the use of chromia-forming metallic interconnects; in fact this phenomenon causes a reduction in the cell performance in terms of a decreased catalytic activity and an increased ion transport resistance at the cathodeelectrolyte interface [1, 16-19].

Specific alloy compositions (e.g., Crofer 22 APU) and numerous coatings (e.g., reactive element oxides, conductive perovskites, conductive spinels and conductive composite spinels) were designed in order to limit the aforementioned problems, particularly for the oxidizing environment of the cathode side [18, 20-24].

The oxidation behavior and oxide scale properties of FSSs can even be influenced by means of alloy microstructure and/or surface treatments (e.g., polishing and grinding) which lead to the modification of the alloy surface roughness $[18,25]$.

The effect of alloy grain size on the formation of a protective external scale on chromia-forming steels was deeply studied by several authors [15, 21, 26-31]. Specifically, chromia-forming alloys with small grain size are characterized by a high density of grain boundaries; in this condition, the formation of a protective $\mathrm{Cr}_{2} \mathrm{O}_{3}$ layer is facilitated because of the high diffusivity of $\mathrm{Cr}$ along the aforementioned planar defects [15]. The influence of surface roughness has been partially investigated, instead $[25,32]$.

This paper arises from the results achieved by the authors [33]. In this work, the aging according to different thermal cycles of many 'as-rolled' K44M-based sheets with two thicknesses (0.6 and $1.5 \mathrm{~mm})$ and different surface roughnesses (higher in the case of the thinner foils because of the further rolling process) highlighted that: a double scale with an inner chromia-rich subscale and an outer $(\mathrm{Mn}, \mathrm{Cr})_{3} \mathrm{O}_{4}$ spinel layer are formed; the latter is continuous in the case of thin samples and discontinuous in the case of the thick ones [33].

In order to understand whether and at which extent the microstructural characteristics of the metallic substrate (i.e., grain size) or its surface roughness influence the features of the formed scales, the authors carried out the study report hereafter.

The oxidation test at the basis of this research reproduces the first step of the operative conditions of a stack that is the thermal treatment applied for the curing of the glass sealing. In the simulated thermal treatment, the atmosphere was the steady laboratory air and no current or mechanical load was applied, as is the case for glass sealing process [34]. The experiment was performed with a commercial FSS, i.e., AISI Type 444. This material has been already used for stacking or simulating stacking of SOFC [17] since it matches all properties requested to an interconnect [35].

\section{Materials and Methods}

\subsection{Materials}

The studied samples, approximatively $15 \times 30 \mathrm{~mm}^{2}$ sized, were mechanically cut from two sheets $(0.4$ and $0.2 \mathrm{~mm}$ thick, respectively) of AISI 444 Type FSS (DIN 1.4521, Eu designation X2CrMoTi18-2) provided by A. P. Steel Srl (Genoa, Italy) in the 'as-rolled' state; the FSS nominal composition is shown in Table 1.

The selected FSS is used in applications where an excellent stability in critical environments such as highpressure water vapor is demanded: steam condensers, heat exchangers, boilers and evaporators, vessels, fumes and pipes, chimney lines, hot water tanks and automotive components [36].

Niobium and titanium act as stabilizing elements of carbon and nitrogen, by inhibiting chromium carbides or nitrides precipitation and thus avoiding, at high temperature, $\mathrm{Cr}$ depletion at grain boundaries; this would increase the sensitivity to oxidation of the ferritic matrix nearby the precipitates (i.e., grain boundaries between carbides and the metal) causing a decreased oxidation resistance [37-39].

Table 1 AISI 444 nominal composition (wt\%) according to A. P. Steel Srl

\begin{tabular}{llllllllll}
\hline $\mathrm{C}$ & $\mathrm{Si}$ & $\mathrm{Mn}$ & $\mathrm{Cr}$ & $\mathrm{Mo}$ & $\mathrm{N}$ & $\mathrm{S}$ & $\mathrm{P}$ & $\mathrm{Ti}+\mathrm{Nb}$ & $\mathrm{Fe}$ \\
\hline 0.013 & 0.54 & 0.24 & 17.63 & 1.87 & $<0.02$ & $<0.02$ & $<0.03$ & 0.48 & Bal. \\
\hline
\end{tabular}


Table 2 Description of studied samples prior to oxidation test

\begin{tabular}{|c|c|c|c|}
\hline $\begin{array}{l}\text { Samples GA-GB } \\
\text { ISO/FEPA grit designation* (average grit size in } \mu \mathrm{m})^{* *}\end{array}$ & Description of the applied surface treatments & Figures & \\
\hline 'As rolled' & & & 目 \\
\hline $\mathrm{P} 320 *(46.2 \mu \mathrm{m})^{* *}$ & Abraded with a P320 SiC paper & & \\
\hline $\mathrm{P} 500 *(30.2 \mu \mathrm{m})^{* *}$ & Abraded with a P500 SiC paper & & \\
\hline $\mathrm{P} 1000 *(18.3 \mu \mathrm{m})^{* *}$ & Abraded with a P1000 SiC paper & & \\
\hline $1 \mu \mathrm{m}$ & Polished up to $1 \mu \mathrm{m}$ diamond suspension & & \\
\hline
\end{tabular}

\subsection{Surface Treatments}

Two groups, each containing FIVE rectangular coupons, were formed and named, respectively, Group A (GA, 0.4mm-thick specimens) and Group B (GB, 0.2-mm thick specimens). The samples were then treated superficially on one side as described in Table 2.

The samples discussed in this paper are each one representative of a set constituted of 20 specimens. For each set, several surface treatments attempts were carried out in order to define the best and reproducible parameters of the experimental work.

Before performing the oxidation tests, part of the samples were polished according to standard ASTM E 3_95 up to $1 \mu \mathrm{m}$ diamond suspension, part superficially treated with different abrasive papers and finally ultrasonically cleaned in petroleum ether and rinsed with ethyl alcohol; the samples named 'as rolled' were only ultrasonically cleaned in petroleum ether and then rinsed with ethyl alcohol. Table 2 shows a short description of the applied surface treatments and pictures of the studied specimens.

According to the applied surface treatment, the specimens were then named as follows: GA 'as-rolled,' GA $46.2 \mu \mathrm{m}$, GA $30.2 \mu \mathrm{m}$, GA $18.3 \mu \mathrm{m}$, GA $1 \mu \mathrm{m}$; GB 'asrolled.' GB $46.2 \mu \mathrm{m}$, GB $30.2 \mu \mathrm{m}$, GB $18.3 \mu \mathrm{m}$, GB $1 \mu \mathrm{m}$.

\subsection{Aging}

All the samples were oxidized inside a muffle furnace, in static air, according to the thermal cycle of Fig. 1. This corresponds to the curing and sintering process of an experimental glass base powder used to seal the air and fuel compartments in the SOFC stack. Sloped intervals have a heating/cooling rate of $2{ }^{\circ} \mathrm{C} / \mathrm{min}$.

After the oxidation test, the oxidation behavior of 'asrolled' and 'superficially treated' samples was evaluated by scanning electron microscopy (SEM), energy-dispersive spectroscopy (EDX), micro-Raman spectroscopy ( $\mu R S)$, and bright field light optical microscopy (LOM-BF).

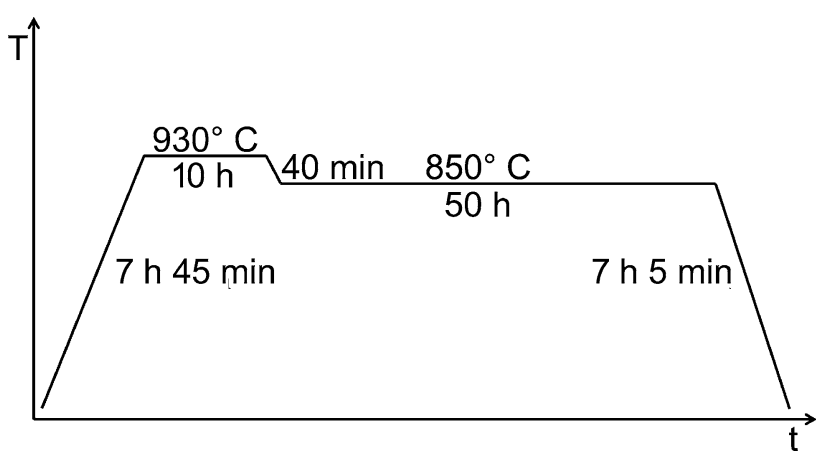

Fig. 1 Applied thermal cycle 
Specifically, the attention was focused on the study of the chemical and morphological peculiarities of the thermally grown oxides (TGOs) and on connecting the collected data with the microstructural and superficial characteristics of the metallic material.

\subsection{Post-experiment Characterization}

The surfaces and the cross sections of all the oxidized samples were analyzed by SEM equipped with EDX. SEM micrographs, showing the morphology of the scales and the elements distribution, were obtained using an acceleration voltage of $20 \mathrm{kV}$ and secondary (SE) and backscattered electrons (BSE) detectors, respectively. The EDX microanalysis was performed with a Pentafet detector sensitive to light elements and connected to INCA 300 software, using an implementing time of $50 \mathrm{~s}$ and applying ZAF 5 correction.

During the cross section preparations, in order to preserve the formed scales, the specimens were first copperplated and then hot-mounted in conductive resin for metallography. The cross sections were then polished according to standard ASTM E 3_95 up to $1 \mu \mathrm{m}$ diamond suspension.

On the basis of SEM-EDX results, a selection of the specimens was characterized 'as aged' by $\mu \mathrm{RS}$. This analysis was carried out with a Renishaw System 2000 spectrometer equipped with a Peltier-cooled CCD detector and coupled with a Leica microscope. The red line at $632.8 \mathrm{~nm}$ of a $\mathrm{He}-\mathrm{Ne}$ laser was used as the excitation source, with laser power kept as low as possible (i.e., from 10 to $50 \%$ transmittance), to avoid sample damage. The measurements were carried out using the following parameters: $50 \times$ objective; recording range from 800 to $200 \mathrm{~cm}^{-1}$; integration time $10 \mathrm{~s}$; number of accumulation from 1 to 25 depending on the samples. Measurements were repeated on different points of the scales surface. To identify the chemical composition of the TGOs, the experimental spectra were compared with data published in the literature [40-45].

The FSS microstructural features were highlighted in cross section, before and after the oxidation tests in the 'asrolled' and surface-treated conditions, by etching with aqua regia $\left(\mathrm{HNO}_{3} / \mathrm{HCl} / \mathrm{H}_{2} \mathrm{O}\right.$ 3:10:10 volume ratio).

Grain sizes of the etched samples were measured by the linear-intercept method (ASTM E112-85) using a Leica MEF 4 metallographic microscope equipped with a computerized image analysis software (Zeiss Axiovision 4) and $25 \times, 50 \times, 100 \times, 200 \times, 500 \times, 1000 \times$ objectives.

The thickness of the oxide scales grown on the 'asrolled' and 'superficially finished' samples was measured on BSE micrographs $(10,000 \times$ magnification) by a computerized image analysis software (Leica QWin), and finally, the measurements of the diameter of TGO crystals were performed with the computerized image analysis software Fiji ImageJ $1.47 \mathrm{~h}$.

\section{Results}

\subsection{Surface Morphology Before Aging}

SEM-SE analyses were performed on surfaces of the samples both groups, i.e., GA (0.4 mm thick) and GB $(0.2 \mathrm{~mm}$ thick), in order to qualitatively evaluate the features of the metallic substrate (i.e., roughness) as a consequence of the applied surface treatments.

Figures 2 and 3 show, respectively, the surfaces of the superficially treated and 'as-rolled' samples before the oxidation test. The density of surface irregularities increases in a directly proportional way to the average grit size of the used abrasive papers (Fig. 2). The 'as-rolled' 0.2-mm-thick specimen (Fig. 3b) exhibits more evident and denser marks due to the rolling process compared to those characterizing the surface of the 0.4-mm-thick specimen (Fig. 3a).

\subsection{Surface Morphology and Chemical Composition After Aging}

The nature and the shape of the oxide crystals grown on the surface of all samples were observed by SEM before performing the procedure of cross section preparation.

Figures 4, 5, 6, 7 and 8 show the morphological characteristics of the oxide crystals of GA samples according to the different surface finishing applied. These pictures are also representative of the peculiarities of those formed on the surfaces of GB samples.

After the aging, the surface textures related to the finishing procedure (i.e., rolling process, grinding with 46.2 , 30.2 and $18.3 \mu \mathrm{m}$ papers) are still clearly visible (Figs. 4, $5,6,8)$.

The samples treated with the different abrasive $\mathrm{SiC}$ papers are characterized by dense oxides layers where well-defined crystals are easily detectable; they are placed mainly in correspondence with the top of the projecting areas (Figs. 4, 5, 6). Smaller oxide crystals with a less defined morphology are also visible (Figs. 4, 5, 6). According to EDX microanalysis, the well-facet crystallites are mainly constituted by $\mathrm{Mn}, \mathrm{Cr}$ and $\mathrm{O}$ (possibly the spinel phase, $\mathrm{MnCr}_{2} \mathrm{O}_{4}$ ), while the small oxide crystals by $\mathrm{Cr}$ and $\mathrm{O}$ (probably the corundum phase, $\mathrm{Cr}_{2} \mathrm{O}_{3}$ ) (Fig. 9; Table 3).

The appearance of the samples polished up to $1 \mu \mathrm{m}$ diamond suspension is completely different. Their surfaces are quite smooth, and FSS grain boundaries are visible and 

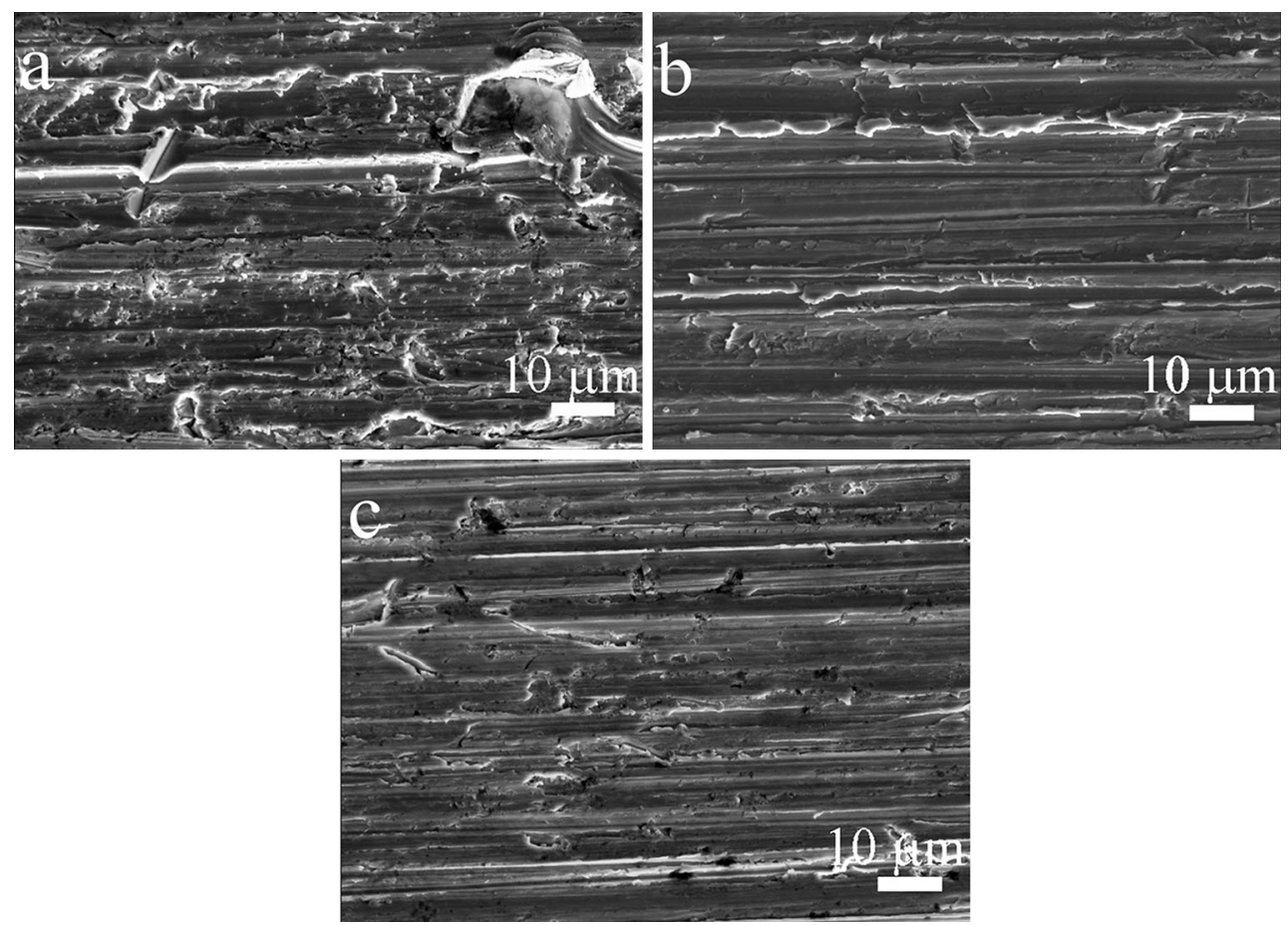

Fig. 2 SEM-SE micrographs showing the FSS surface after the finishing with $46.2 \mu \mathrm{m}$ a, $30.2 \mu \mathrm{m} \mathbf{b}, 18.3 \mu \mathrm{m}$ c abrasive SiC papers
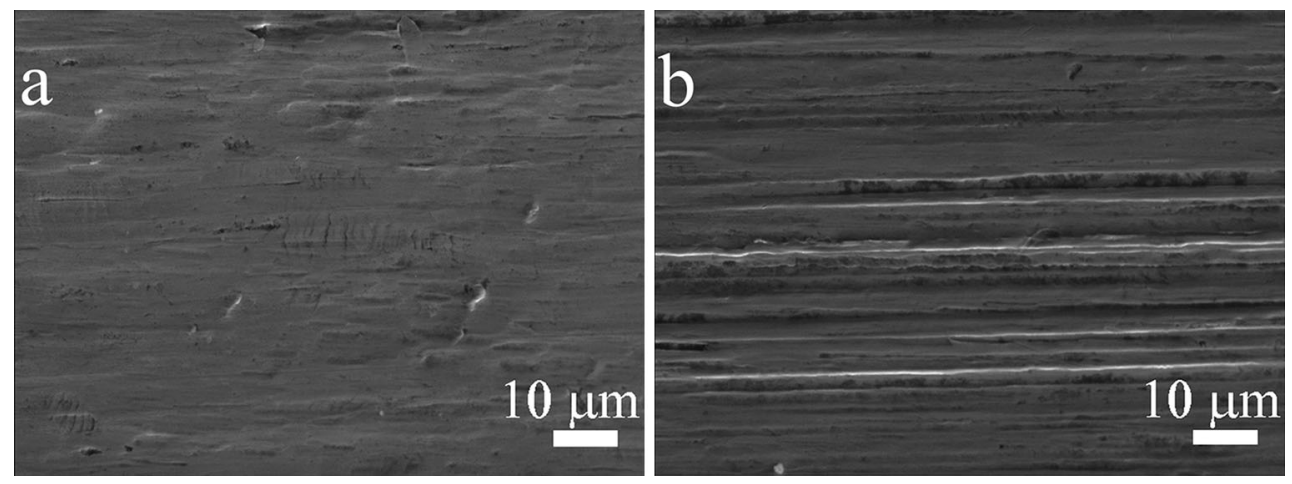

Fig. 3 SEM-SE micrographs showing the FSS surface of the 'as-rolled' samples: group GA a, GB b
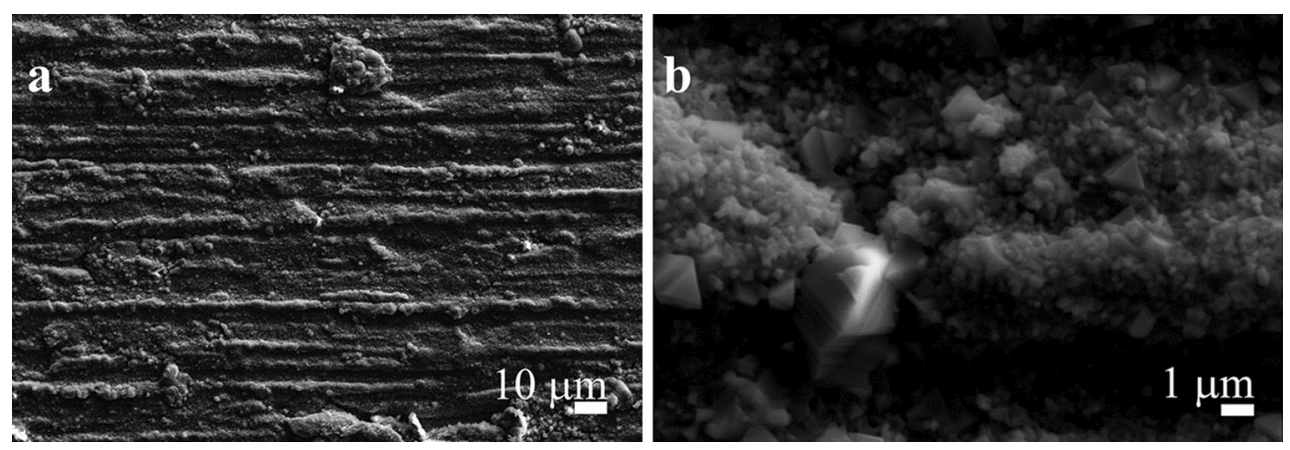

Fig. 4 SEM-SE micrographs showing the surface of the sample GA $46.2 \mu \mathrm{m}$ at different magnifications: $\times 1500$ a, $\times 15,000 \mathbf{b}$

highlighted by the presence of larger oxide crystals with the following elemental composition: Mn, Cr, O (Figs. 7a, b, 10; Table 4). Except for the few large crystallites at the grain boundaries, the surface of these specimens exhibits mainly small crystals with homogeneous dimensions principally constituted by $\mathrm{Cr}$ and $\mathrm{O}$ (Fig. 10; Table 4). 

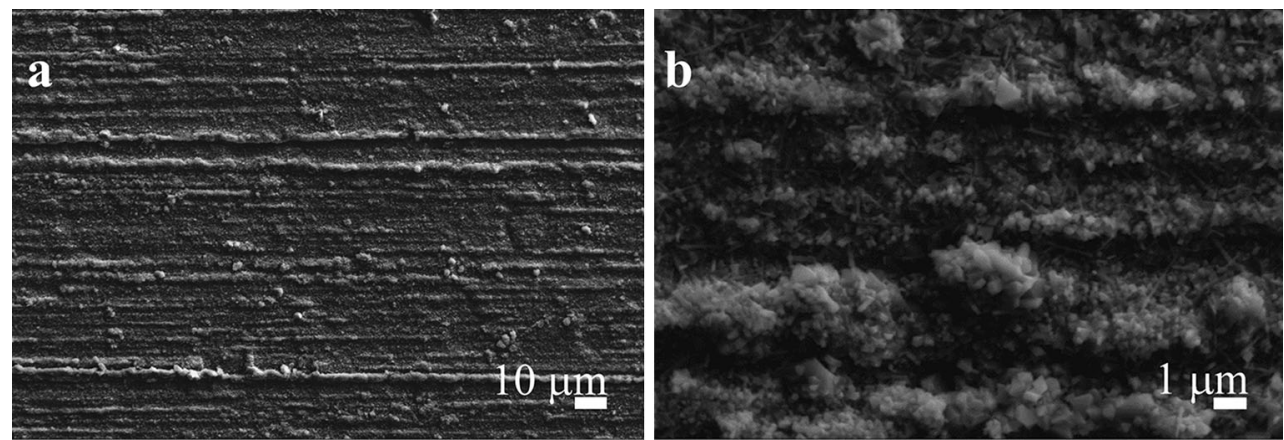

Fig. 5 SEM-SE micrographs showing the surface of the sample GA $30.2 \mu \mathrm{m}$ at different magnifications: $\times 1500 \mathbf{a}, \times 15,000 \mathbf{b}$
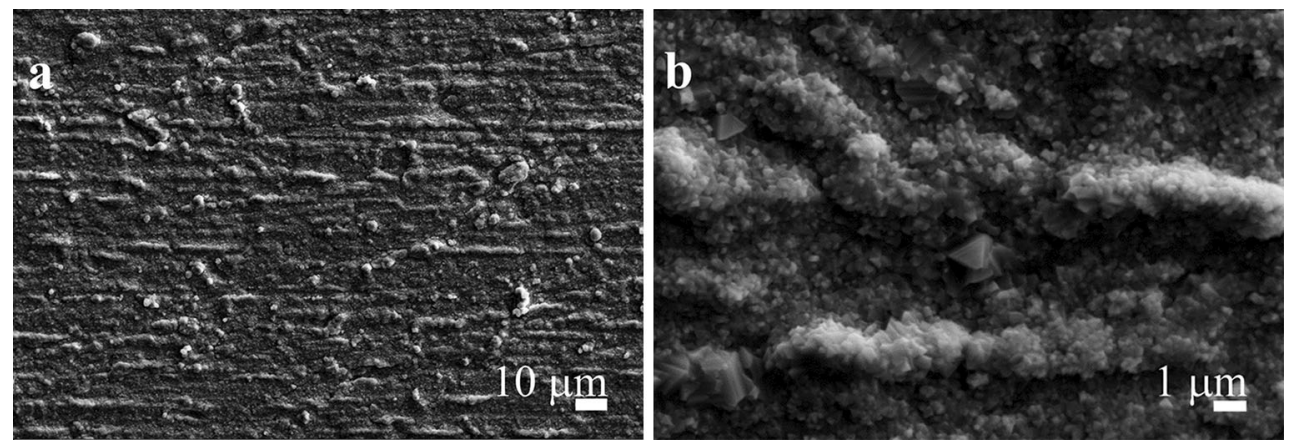

Fig. 6 SEM-SE micrographs showing the surface of the sample GA $18.3 \mu \mathrm{m}$ at different magnifications: $\times 1500$ a, $\times 15,000 \mathbf{b}$
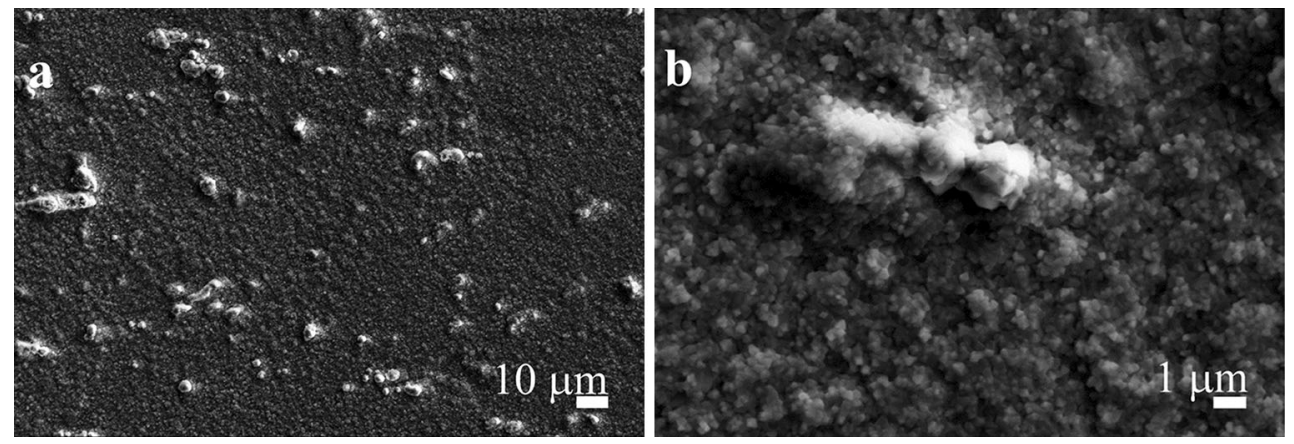

Fig. 7 SEM-SE micrographs showing the surface of the sample GA $1 \mu \mathrm{m}$ at different magnifications: $\times 1500 \mathbf{a}, \times 15,000 \mathbf{b}$
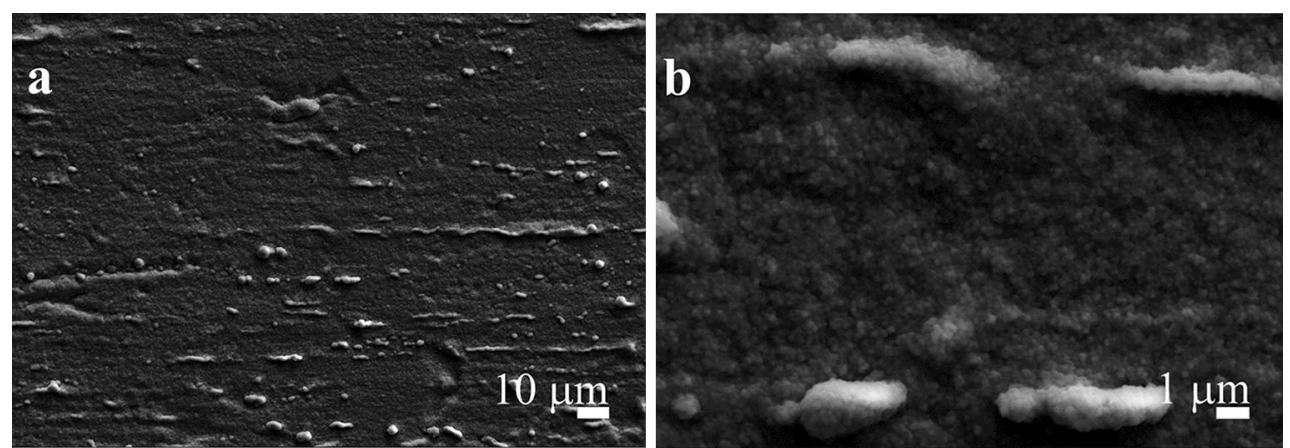

Fig. 8 SEM-SE micrographs showing the surface of the sample GA 'as rolled' at different magnifications: $\times 1500 \mathbf{a}, \times 15,000 \mathbf{b}$ 


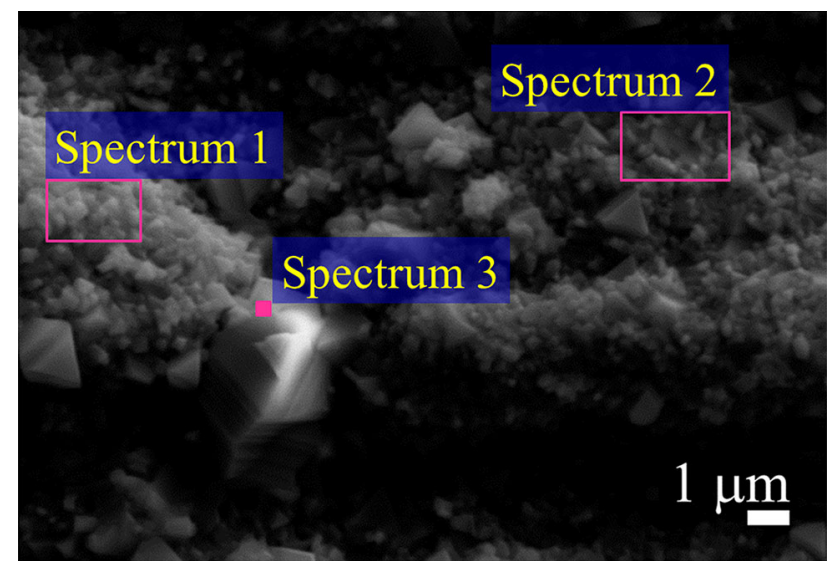

Fig. 9 SEM-SE micrograph of the sample GA $46.2 \mu \mathrm{m}$; spot and areas of EDX analysis

Table 3 Results of EDX analysis (at.\%), sample GA $46.2 \mu \mathrm{m}$

\begin{tabular}{lllr}
\hline Spectrum & O & Cr & Mn \\
\hline Spectrum 1 & 44 & 37 & 19 \\
Spectrum 2 & 44 & 48 & 8 \\
Spectrum 3 & 28 & 41 & 31 \\
\hline
\end{tabular}

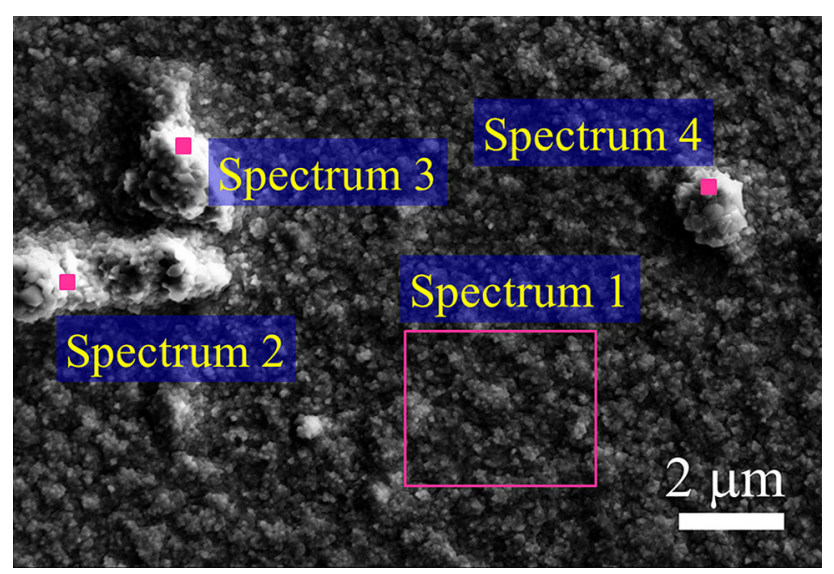

Fig. 10 SEM-SE micrograph of the sample GA $1 \mu \mathrm{m}$; spots and areas of EDX analysis

Table 4 Results of EDX analysis (at.\%), sample GA $1 \mu \mathrm{m}$

\begin{tabular}{lllr}
\hline Spectrum & O & Cr & Mn \\
\hline Spectrum 1 & 56 & 35 & 9 \\
Spectrum 2 & 46 & 35 & 19 \\
Spectrum 3 & 46 & 35 & 19 \\
Spectrum 4 & 60 & 28 & 12 \\
\hline
\end{tabular}

A dense oxide layer constituted by small crystals (Fig. 11) with the composition shown in Table 5 covers the surface of 'as-rolled' samples; from this layer, clusters of

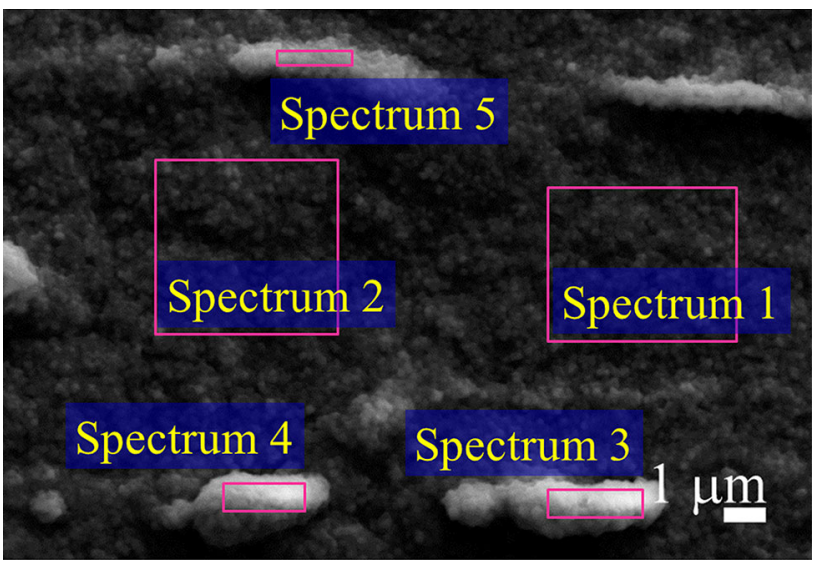

Fig. 11 SEM-SE micrograph of the sample GA 'as rolled'; spot and areas of EDX analysis

Table 5 Results of EDX analyses (at.\%), sample GA 'as rolled'

\begin{tabular}{lllr}
\hline Spectrum & O & Cr & Mn \\
\hline Spectrum 1 & 59 & 33 & 8 \\
Spectrum 2 & 59 & 33 & 8 \\
Spectrum 3 & 59 & 27 & 14 \\
Spectrum 4 & 52 & 32 & 16 \\
Spectrum 5 & 51 & 36 & 13 \\
\hline
\end{tabular}

crystallites characterized by an higher Mn concentration arise (Fig. 11; Table 5).

By the sole surface observation, it seems that the spinel layer does not completely cover the chromia-based layer. This situation was already noticed by Magdefrau et al. [21] after $750 \mathrm{~h}$ of high-temperature oxidation test of Crofer 22 APU. However, in this case, only the cross section investigations can give a more detailed vision of the spinel oxide distribution over the chromia scale.

By measuring the average size of spinel crystals forming the TGO layer, it is possible to highlight a correlation between such a measure and the applied surface finishing. From the graph of Fig. 12, which is the representative of both groups of the samples, it is evident that the higher the concentration of nucleation sites (i.e., geometrical defects left in the abrasion traces) on the surface, the smaller the size of the spinel crystals formed. This is coherent with the number of nucleation sites, which is lowering when the number of superficial defects left by the surface treatments diminishes. A limited number of nucleation sites correspond then to a grain growth phenomenon more important than grain formation. From the diagram of Fig. 12, it is even possible to deduce that the oxidation behavior of 'asrolled' samples is close to that of the samples treated with the $30.2-\mu \mathrm{m}$ abrasive paper. 


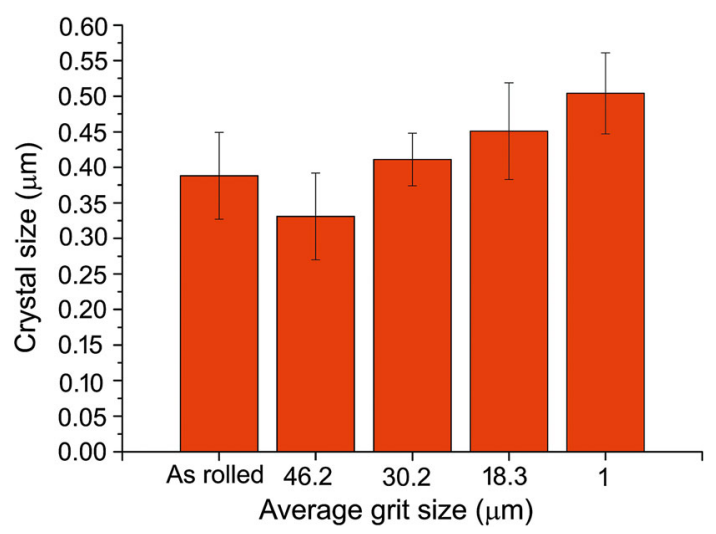

Fig. 12 Average size of surface crystals grown on GA samples

\subsection{Cross Sections Characterization}

Different analyses were performed on all samples cross sections (i.e., SEM-BSE, LOM-DF, EDX microanalysis and $\mu \mathrm{RS})$ in order to highlight the morphological and chemical peculiarities of the TGOs as the adherence to the FSS substrate, the presence of cracks, the thickness and finally the chemical composition.

\subsubsection{TGO Thickness Measurements}

As it is possible to note by observing BSE micrographs showing samples cross sections after the short-term oxidation test (Table 6), the oxide scales are all adherent to the FSS substrate and the profiles of the metallic surfaces appear:

1. rough, with grooves and projections, when the various abrasive $\mathrm{SiC}$ papers were used;

2. quite smooth in the case of the application of treatments as cold rolling and polishing up to $1 \mu \mathrm{m}$ diamond suspension.

The average thicknesses of the TGOs formed on the samples are in the same range, with the exception of sample GA $1 \mu \mathrm{m}$ (Table 7).

To better use the TGO thickness data, a statistical distribution was made and the percentage frequency of thickness values compared in the graphs of Fig. 13. The thickness distributions result comparable for GA and GB samples abraded with the $46.2,30.2$ and $18.3 \mu \mathrm{m} \mathrm{SiC}$ papers (Fig. 13a-c). It is worth noting that, inside this group of the samples, the thickness distributions of those finished with the $30.2 \mu \mathrm{m} \mathrm{SiC} \mathrm{paper} \mathrm{are} \mathrm{slightly} \mathrm{shifted}$ toward lower values (Fig. 13b).

The thickness distributions of GA and GB coupons polished up to $1 \mu \mathrm{m}$ diamond suspension (Fig. 13d) represent a characteristic case, since they clearly diverge. Moreover, the thickness of the oxide scale grown on GA sample is lower if compared to those of GB (Fig. 13d).
In the case of 'as-rolled' specimens it is possible to note a slight difference in the distribution of the thickness with a shift of the average values coherent with what was observed for the samples polished up to $1 \mu \mathrm{m}$ diamond suspension. A different oxidation behavior connected with the samples thickness starts to be visible only for FSS sheets characterized by a low surface roughness (i.e., $1 \mu \mathrm{m}$ diamond suspension and 'as-rolled' samples).

Taking into account graphs of Fig. 13 again, it is possible to infer that the superficial roughness strongly influences the FSS oxidation behavior. In effect, the TGO thickness distributions of all the superficially treated specimens belonging to both groups follow the same trends which are affected only by the selected abrasive papers. In this particular case, the presence of superficial imperfections seems to have more consistent effect, on the scale growth, than other specimens peculiarities (e.g., the FSS microstructure). As it is known, an increase in surface defects corresponds as well to an increase in the surface area and of the preferred nucleation sites [20].

\subsubsection{FSS Microstructural Characterization}

In order to further contribute to the discussion of the observed phenomena, the microstructural features of the FSS substrate were studied before and after the oxidation test in the 'as-rolled' and surface-treated state (Table 8; Figs. 14, $15)$.

Due to the texture resulting from the cold rolling process, the grain size was measured on the longitudinal cross section (parallel to elongation) and on the transverse cross section (orthogonal to the rolling direction).

The oxidation process can be considered as a thermal treatment carried out at high temperature for a quite long time. During this period, it is possible to observe the evolution of the grain size.

Assuming that the oxidation test was carried out at temperatures higher than the recrystallization temperature, a number of phenomena took place: recovery, recrystallization and grain coarsening.

Before the thermal treatment, the microstructure of GB samples resulted too fibrous to allow any grain size measurement. After the thermal treatment, GA samples show a relaxation of the grain with an increase in the orthogonal grain size (Fig. 14b), while GB samples are characterized by a smaller grain size than GA ones (Fig. 15b). This is coherent with the high amount of cold working accumulated during shaping (Fig. 15a).

In particular, the mechanical treatment applied to reach the requested thickness (i.e., $0.2 \mathrm{~mm}$ ) introduced dislocations into FSS and upon heating to recrystallization temperature, a finer-grained microstructure originated [25, 46]. 
Table 6 SEM-BSE micrographs of aged samples from group GA (0.4 mm thick) and GB (0.2 mm thick)

Applied thermal cycle: $10 \mathrm{~h} / 930^{\circ} \mathrm{C}$ and $50 \mathrm{~h} / 850{ }^{\circ} \mathrm{C}$ (Fig. 1)

\begin{tabular}{ll}
\hline GA samples $(0.4 \mathrm{~mm}$ thick $)$ & GB samples $(0.2 \mathrm{~mm}$ thick$)$
\end{tabular}

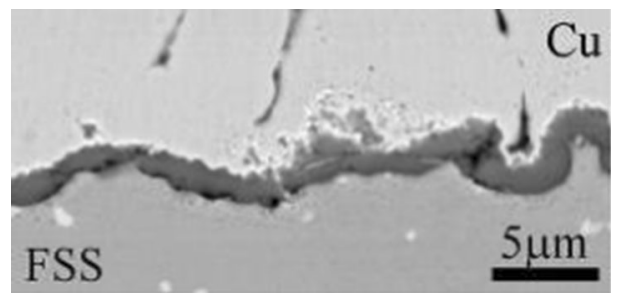

SEM-BSE micrograph (magnification $10,000 \times$ ), sample GA $46.2 \mu \mathrm{m}$

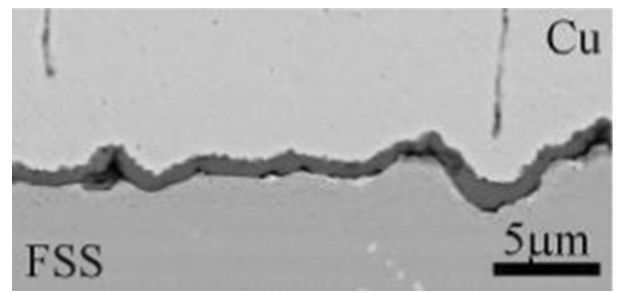

SEM-BSE micrograph (magnification 10,000×), sample GA $30.2 \mu \mathrm{m}$

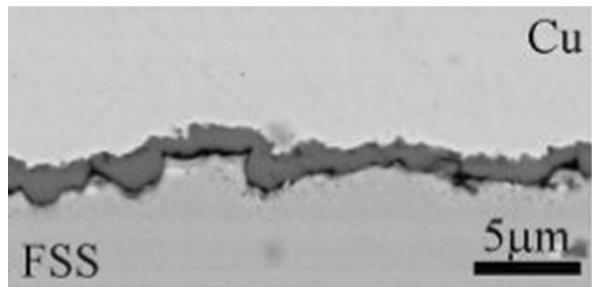

SEM-BSE micrograph (magnification 10,000×), sample GA $18.3 \mu \mathrm{m}$

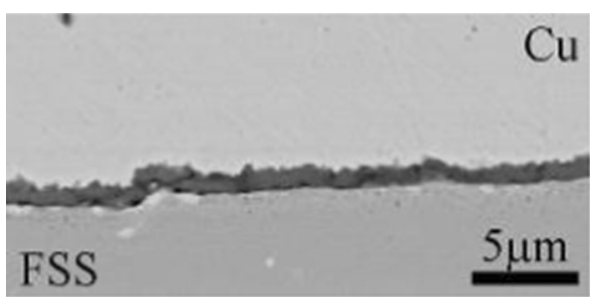

SEM-BSE micrograph (magnification 10,000×), sample GA $1 \mu \mathrm{m}$

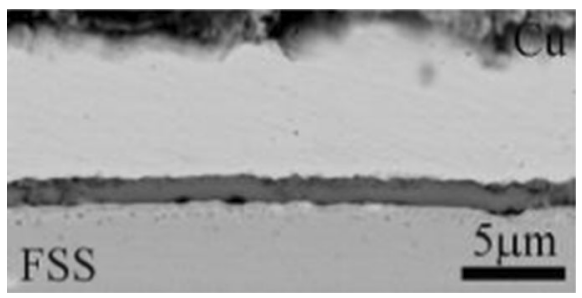

SEM-BSE micrograph (magnification 10,000×), sample GA 'as rolled'

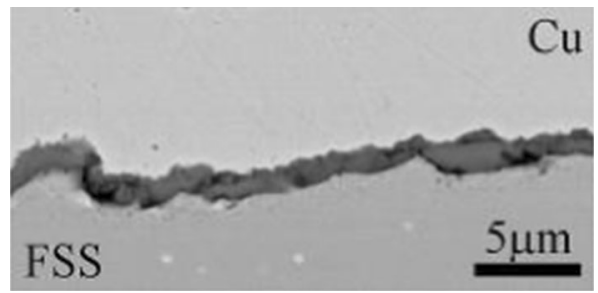

SEM-BSE micrograph (magnification 10,000×), sample GB $46.2 \mu \mathrm{m}$

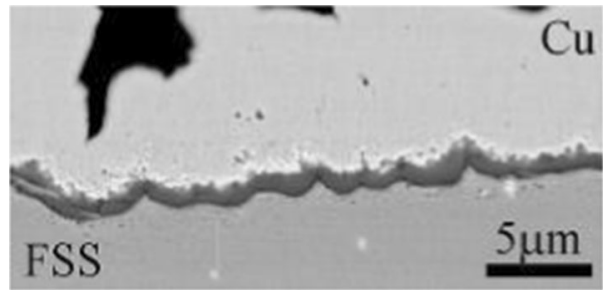

SEM-BSE micrograph (magnification 10,000×), sample GB $30.2 \mu \mathrm{m}$

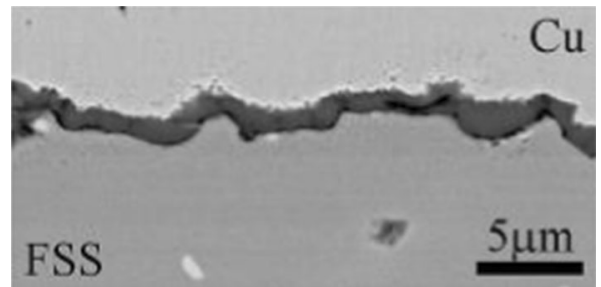

SEM-BSE micrograph (magnification 10,000×), sample GB $18.3 \mu \mathrm{m}$

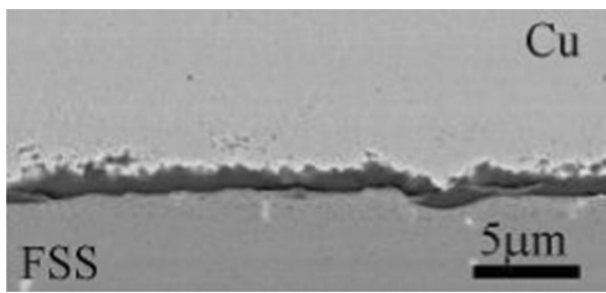

SEM-BSE micrograph (magnification 10,000×), sample GB $1 \mu \mathrm{m}$

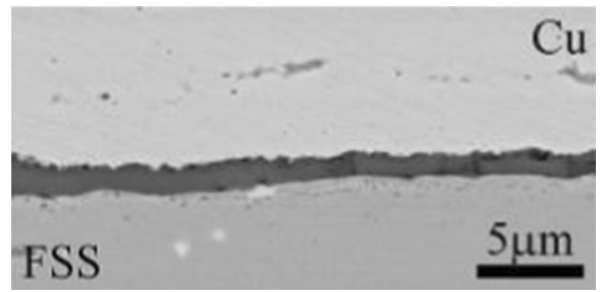

SEM-BSE micrograph (magnification 10,000×), sample GB 'as rolled'

\subsection{TGO Chemical Characterization}

The chemical nature of the TGOs was studied through EDX microanalysis and $\mu$-RS (Figs. 16, 17). All samples gave comparable results, which are summarized in the following points:

1. Fe shows limited diffusion into the oxide layer; 
Table 7 Average TGO thickness $(\mu \mathrm{m})$ calculated out of a statistical evaluation of the scale thickness in several different locations across the cross sections

\begin{tabular}{lll}
\hline Surface treatment & $\begin{array}{l}\text { Samples GA } \\
\text { Average TGO thickness }(\mu \mathrm{m})(\mathrm{SD}, \mu \mathrm{m})\end{array}$ & $\begin{array}{l}\text { Samples GB } \\
\text { Average TGO thickness }(\mu \mathrm{m})(\mathrm{SD}, \mu \mathrm{m})\end{array}$ \\
\hline $46.2 \mu \mathrm{m}^{\mathrm{a}}$ & $1.51(0.44)$ & $1.50(0.78)$ \\
$30.2 \mu \mathrm{m}^{\mathrm{a}}$ & $1.23(0.39)$ & $1.15(0.28)$ \\
$18.3 \mu \mathrm{m}^{\mathrm{a}}$ & $1.49(0.49)$ & $1.46(0.52)$ \\
$1 \mu \mathrm{m}$ & $1.04(0.19)$ & $1.17(0.58)$ \\
'As rolled' & $1.26(0.36)$ & $1.42(0.20)$ \\
\hline
\end{tabular}

${ }^{a}$ Average grit size of the abrasive $\mathrm{SiC}$ paper
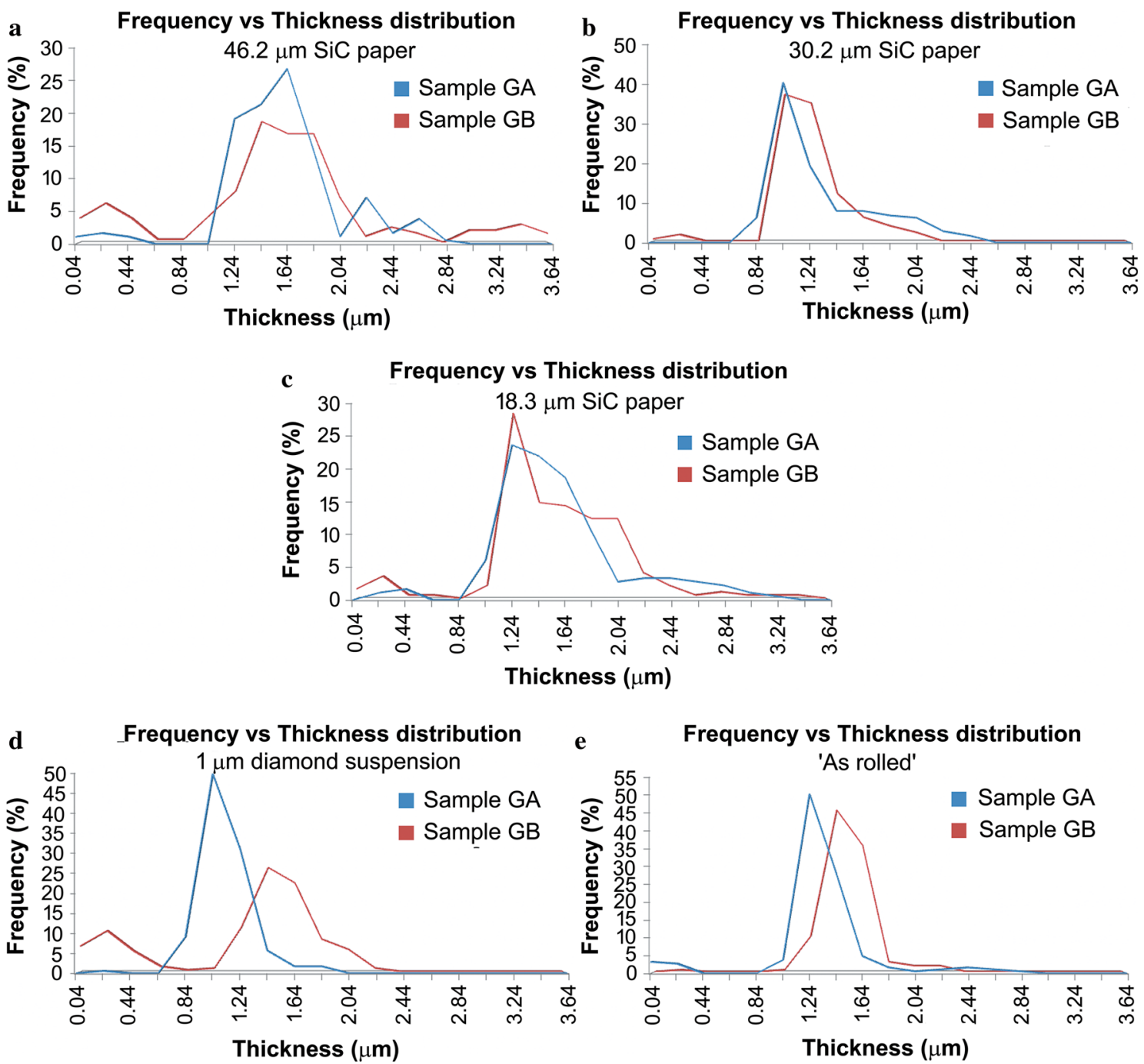

Fig. 13 Frequency of thickness distribution in function of the surface treatments, samples GA and GB

2. $\mathrm{Cr}$ is mainly concentrated in the inner part of the TGO nearby the FSS substrate;

3. $\mathrm{Mn}$ is primarily distributed inside the oxide layer, mainly in the external part of the TGO;

4. Si and $\mathrm{Ti}$ are mainly segregated at the TGO/FSS interface.
$\mu-\mathrm{RS}$, carried out on different points of all samples cross sections, allowed to identify the following compounds: $\mathrm{Cr}_{2} \mathrm{O}_{3}$ and $\mathrm{Mn}_{x} \mathrm{Cr}_{3-x} \mathrm{O}_{4}$ (Fig. 17) [40-45]. $\mu-\mathrm{RS}$ results together with SEM observations of cross sections confirmed and better specified the biphasic nature of the TGO scale. All samples, independently from the thickness and 
Table 8 Average grain size $(\mu \mathrm{m})$ measured along and orthogonally with respect to the rolling direction on both group of samples before and after the oxidation test

\begin{tabular}{|c|c|c|}
\hline & \multicolumn{2}{|c|}{ Average grain size $(\mu \mathrm{m})(\mathrm{SD}, \mu \mathrm{m})$} \\
\hline & Parallel to elongation & Orthogonally to the rolling direction \\
\hline GA—before oxidation test (Fig. 14a) & $24.70(1.54)$ & $13.32(0.67)$ \\
\hline GA-after the oxidation test (Fig. 14b) & $23.07(1.78)$ & $19.54(0.95)$ \\
\hline GB-before the oxidation test (Fig. 15a) & \multicolumn{2}{|c|}{ Strongly textured material: no grain size measurements were possible } \\
\hline GB-after the oxidation test (Fig. 15b) & $9.98(0.93)$ & $14.35(0.58)$ \\
\hline
\end{tabular}

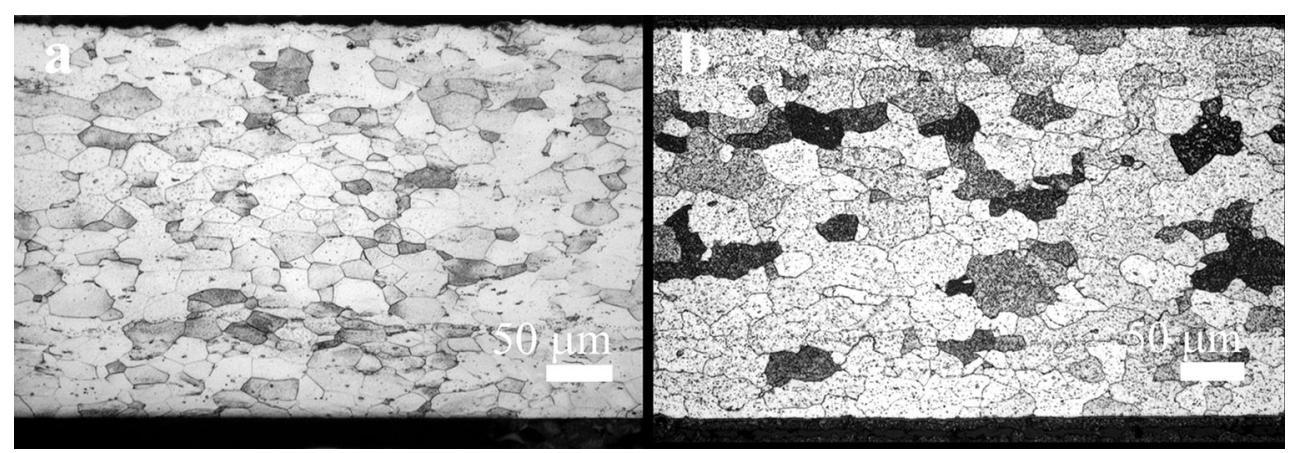

Fig. 14 LOM-BF micrographs of the 'as-rolled' samples belonging to GA group before a and after oxidation test $\mathbf{b}$, etching with aqua regia
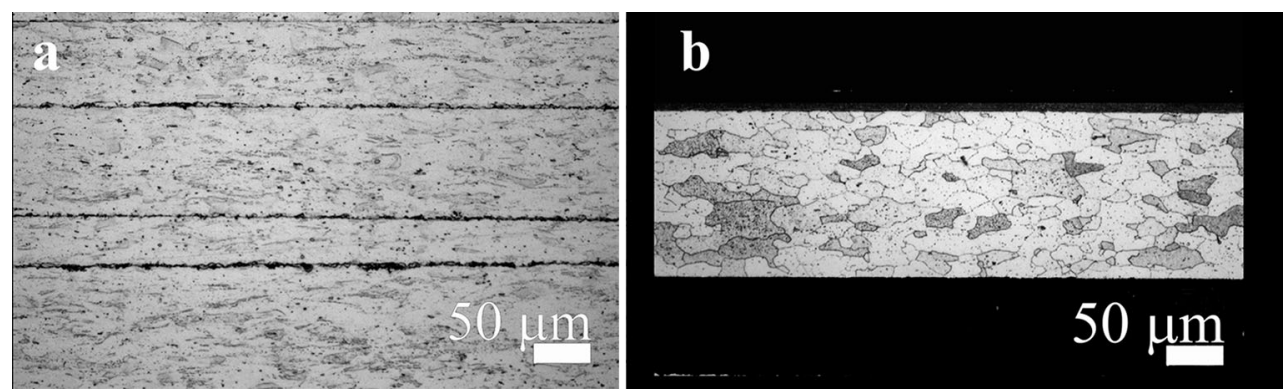

Fig. 15 LOM-BF micrographs of the 'as-rolled' samples belonging to GB group before a and after oxidation test b, etching with aqua regia

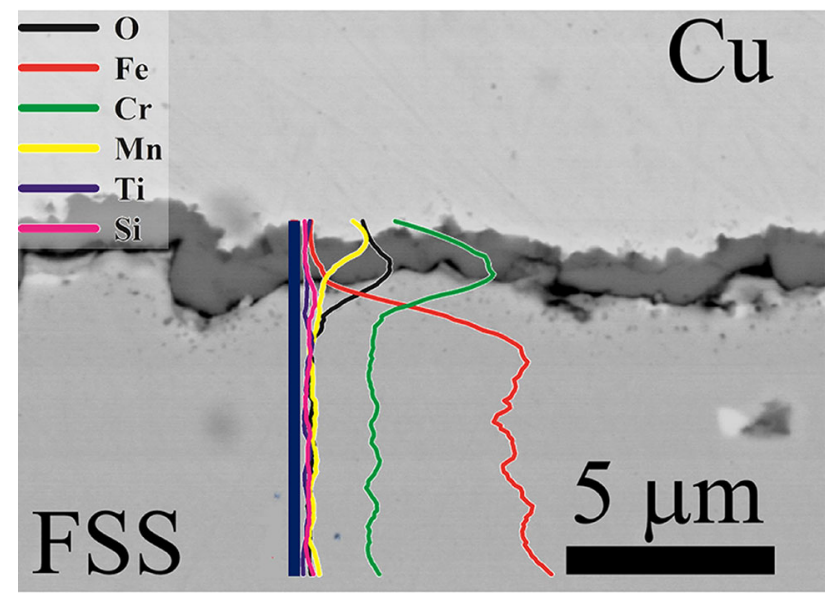

Fig. 16 BSE micrograph of the sample GB $30.2 \mu \mathrm{m}$ with EDX semiquantitative distribution profiles of elements

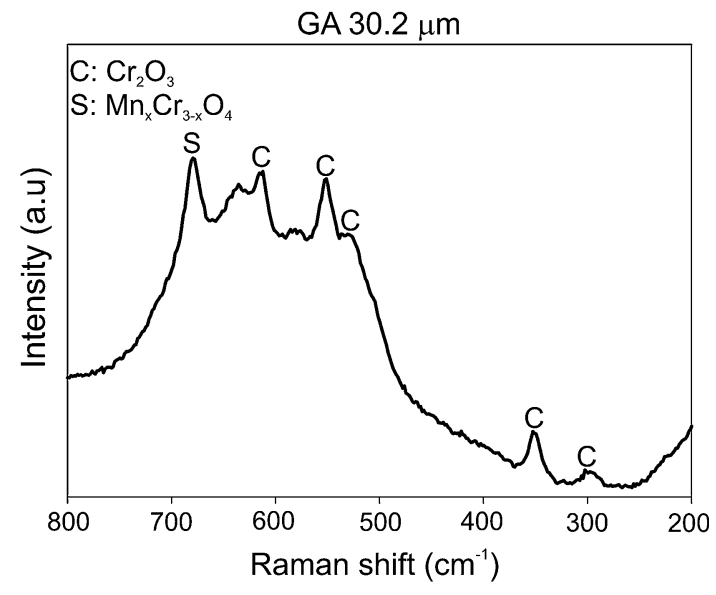

Fig. 17 Raman spectrum of the sample GA $30.2 \mu \mathrm{m}$ 
applied surface treatment, show outer and continuous layers made of $(\mathrm{Cr}, \mathrm{Mn}) 3 \mathrm{O} 4$ spinels covering inner layers made of $\mathrm{Cr}_{2} \mathrm{O}_{3}$. The latter are in direct contact with the metallic substrate.

\section{Discussion}

The collected data confirmed the expected result of a dual oxide layer, consisting of an inner $\mathrm{Cr}_{2} \mathrm{O}_{3}$ subscale and an outer $(\mathrm{Mn}, \mathrm{Cr})_{3} \mathrm{O}_{4}$ spinel layer (Tables 3, 4, 5; Figs. 9, 10, $11,16,17)[22,47-53]$.

$\mathrm{Mn}-\mathrm{Cr}$ spinels layers are welcome since their presence improves the overall scale conductivity and $\mathrm{Cr}$ stability in the oxide $[52,54-59]$. The latter phenomenon is of dramatic importance in SOFC stacks under operation where $\mathrm{Cr}_{2} \mathrm{O}_{3}$ further oxidized to $\mathrm{CrO}_{3}$ and $\mathrm{Cr}(\mathrm{OH})_{2} \mathrm{O}_{2}$ causing the chromium poisoning of the cathode and the pollution of the sealant [34] and involving a rapid degradation of the cell performance and a change of stack durability [1,22].

$\mathrm{Si}$ and $\mathrm{Ti}$ were also concentrated at the scale/FSS interface where they, respectively, form silica [60] and Tirich oxides. Their presence is expected in commercial FSS but, due to their negative effect on the resulting conductivity, alloying elements are introduced to fix silicon into Laves phases [61], while Ti forms isolated oxides contributing to limit $\mathrm{Cr}$ volatility [1].

The usage of coatings specifically designed to hinder the Cr poisoning phenomenon is a common solution [5, 22, 62]; however, most of the stack designs apply such solution to a portion of the metal plates for economic issues. It is therefore meaningful and interesting to understand how the surface finishing affects the FSS oxidation process.

This was thus the purpose of the present research observing the microstructural and morphological peculiarities of the oxide scales (i.e., adherence to the metal substrate, $\mathrm{Cr}$ and $\mathrm{Mn}$ crystals oxides size, thickness, density) formed on commercial FSS with two different thicknesses in correlation with the surface state (i.e., different roughness due to various surface finishing) and microstructural features (e.g., grain size).

The oxide scales are all adherent to the FSS substrate with few dark areas localized at the scale/alloy interface (they are rather visible in micrographs of Tab. 6 showing the oxide layers of samples GA $46.2 \mu \mathrm{m}$, GA $30.2 \mu \mathrm{m}$, GA $18.3 \mu \mathrm{m}, \mathrm{GA} 1 \mu \mathrm{m}, \mathrm{GA}$ 'as rolled' and GB $46.2 \mu \mathrm{m})$. Such areas were interpreted as a material loss due to the procedure of cross sections preparation.

The absence of micro-defects (e.g., cracks) in the TGO depends on the application, during the oxidation test, of suitable heating/cooling rates. This limited the common causes of contact loss between the oxide layers and the alloy as growth thermomechanical stresses at the scale/substrate interface, and TEC mismatch induced stresses between the TGO and the metallic substrate $[18,63-65]$. The excellent adhesion is furthermore increased by the roughness resulting from the applied surface finishings (Figs. of Table 6) [18, 66].

Grain size of the metallic substrate was measured and compared between the two thicknesses. The thinner, further cold-rolled specimens show as expected smaller grains (i.e., half-sized) than the thicker FSS specimens. The decreased grain size derives from recrystallization phenomena occurred during the oxidation process at high temperatures of the cold worked steel. The Laves phases, precipitated at the grain boundaries, counteract the grain growth [67].

The smaller grain size of the thinner FSS samples corresponds essentially to a higher density of the grain boundaries exposed to oxidation at the surface [25, 46]. An evidence of how the microstructural features affect the oxidation process at high temperature is provided by the mirror-like polished samples only. TGO of the sample GB$1 \mu \mathrm{m}$ is thicker than the one of the sample GA $1 \mu \mathrm{m}$ (Fig. 13d; Table 7). This suggests, for the thin specimen, a higher oxidation rate [25].

The density of the grain boundaries on the polished surface corresponds to a larger number of available oxide nucleation sites, since the diffusion rate of ions involved in the scale formation is orders of magnitude faster along the grain boundaries than across the bulk $[21,56]$. Figures $7 \mathrm{a}$, b, 10 and the results of EDX microanalysis (Table 4) highlight such phenomenon by showing the presence of $\mathrm{MnCr}_{2} \mathrm{O}_{4}$ crystals. Their formation is promoted by the high diffusivity of $\mathrm{Mn}$ ions through chromia (i.e., 1-2 orders of magnitude faster than grain boundary diffusion of $\mathrm{Cr}$ or $\mathrm{Fe}$ in $\mathrm{Cr}_{2} \mathrm{O}_{3}$ ). The following statement can therefore be explained: the higher the grain boundary density at the surface, the larger the number of spinel crystals on top of the chromia scale [21, 48].

GA and GB samples are both submitted to the high-temperature oxidation process right after cold rolling thus at the 'as-deformed' state followed when planned by surface abrading procedure. As previously stated, GB specimens were sampled from a sheet resulting from further cold deformation of GA steel. An increased cold hardening of the metal matrix resulting in a higher volume density of lattice defects is therefore expected. It is known that this should affect the reactivity of the metal substrate once submitted to an oxidation process. Moreover, the cold rolling process applies an increase in internal energy (cold hardening) in the metal with a gradient due to the skill of the metal matrix to absorb and mitigate the effort. This corresponds to a higher cold deformation on the superficial volume decreasing when moving toward the core of the cross section. The micrographs of Figs. 14 and 15 confirm the previous sentences 
showing a more deformed microstructure for GB than for GA in 'as-rolled' samples, smaller grain size for GB than for GA after oxidation (i.e., resulting from a recrystallization annealing occurred during th high-temperature oxidation process), and for both GA and GB samples after oxidation an even smaller grain size at the external edge of the cross section. The specimen better showing the effect of the initial microstructural state on the scale formation are those mirrorlike polished due to the absence of superficial factors affecting the final result. The two samples are clearly distinguished, and the higher reactivity of GB polished specimen could be justified by both the higher defects density and the smaller grain size on GB samples. It is, however, worth to note that: 1) the recrystallization process occurs in the range 500-600 ${ }^{\circ} \mathrm{C}$ (i.e., $1 / 3$ of the melting point) after the recovery process (i.e., dislocations of opposite sign reciprocal annihilation preceding the nucleation of recrystallization) which happens at even lower temperature; 2) as previously published [33], below $600{ }^{\circ} \mathrm{C}$ the formation of TGO on the surface of such FSS is very low and corresponds to a diffused nanoscopic layer with some crystals mainly sporadically distributed on the surface. According to these details one can assume that the samples recrystallize during the first step of the thermal treatment (Fig. 1) drastically reducing the number of dislocations and increasing the grain boundaries arising to the surface then, at a temperature higher than $600{ }^{\circ} \mathrm{C}$, the scale formation starts and the diffusion process through grain boundaries become the main source of metal ions to form the TGO.

The process of abrasion of metallic surfaces produces a roughness characterized by grooves with width and depth proportional to the average grit size of the used grinding papers (Fig. 2; Table 6). The post-oxidation investigation (Fig. 13) highlighted that for the abraded surfaces the TGO thicknesses are homogeneous and not affected by the microstructural features of the metal substrate. The thicknesses of the oxide scale start to differ only when the samples surfaces were polished by $1 \mu \mathrm{m}$ diamond suspension and in the case of 'as-rolled' samples. This suggests that the microstructural features (i.e., FSS grain size and grain boundaries density) start to affect the oxides formation when the metal surfaces are treated by papers with average grit size below $18.3 \mu \mathrm{m}$, i.e., the finest grit size used during the finishing procedures.

As a consequence of the grinding process, the surface has a specific roughness due to the grain size of the silicon carbide on the paper. The external edge is nearly amorphous with a nearly complete loss of crystalline lattice and with a strong tendency to reach the recrystallized steady state under thermal treatment. Such an amorphous superficial layer is characterized by the highest structural defects concentration [25] (acting as short circuit of diffusion) and a larger reacting surface. Both aspects affect the scale formation by speeding up the TGO nucleation and growth processes. It is worth to note that this effect is limited to the first heating stage while the top layer is still amorphous. Above $600{ }^{\circ} \mathrm{C}$, as previously stated, the whole sample is recrystallized with eventually smaller grains at the external edge. This corresponds to an increased number of grain boundaries arising to the surface which contribute effectively to the final formation of the scale. Starting from this stage, mainly the grain boundaries act as short circuit of diffusion bringing the needed metal ions (i.e. $\mathrm{Mn}, \mathrm{Cr}$ ) to the TGO.

Taking into account the graphs of Fig. 13, the 'as-rolled' samples represent an intermediate situation between those finished with $1 \mu \mathrm{m}$ diamond suspension and those treated with the abrasive papers. SEM measurements of samples surfaces and cross sections and the measurements of the size of spinel crystals allowed for observing that the morphology of TGOs of 'as-rolled' specimens can be compared with that of the scales grown on surfaces treated with the $18.3 \mu \mathrm{m}$ and $30.2 \mu \mathrm{m}$ papers. In fact, these samples are characterized by $\mathrm{Mn}-\mathrm{Cr}$ spinels with quite regular dimensions on the top of dense inner chromia layers.

During the handling of metallic structural materials to manufacture SOFC stacks, it is necessary to contemplate all the aforementioned aspects [25]. The formation of a stable scale on top of not coated areas makes such steel favorite than other materials. A suitable mechanical surface treatment or simply the as-rolled surface may thus respond to such request when the correct FSS is used.

\section{Conclusions}

This paper explores the high-temperature oxidation behavior of AISI Type 444 commercial FSS according to the microstructural features and the applied surface finishing.

The studied samples ( 0.4 and $0.2 \mathrm{~mm}$ thick) were aged after the application of various surface treatments (SiC papers with differing average grit size, i.e., 46.2, 30.2 and $18.3 \mu \mathrm{m})$ in order to have a controlled and engineered surface roughness. Up to $1 \mu \mathrm{m}$ diamond suspension polishing and 'as-rolled' surfaces were also oxidized with the aim of investigating the two extreme conditions.

The 0.2-mm-thick specimens (Group B, GB) were also distinguished by a finer grain size due to the further thickness reduction by cold rolling of the original $0.4-\mathrm{mm}$ FSS sheets (Group A, GA).

The surface roughness increases proportionally with the average grit size of the used grinding papers, whereas the 'as-rolled' surfaces appear quite smooth, namely in an intermediate situation between a mirror-like surface and a 
surface grinded with a $18.3 \mu \mathrm{m}$ abrasive $\mathrm{SiC}$ paper.The gathered data allowed for the following conclusions:

1. all samples are characterized by TGOs consisting of an inner $\mathrm{Cr}_{2} \mathrm{O}_{3}$ subscale and an outer $(\mathrm{Mn}, \mathrm{Cr})_{3} \mathrm{O}_{4}$ spinel layer;

2. only mirror-like polished samples show the evidence of the relationship between the FSS grain size and the scale microstructural aspects;

3. despite the different surface treatments, all FSS samples are characterized by a comparable thickness of the TGOs;

4. the 'as-rolled' surfaces are characterized by continuous scales morphologically similar to those grown on the surfaces finished with the $30.2-\mu \mathrm{m}$ and $18.3-\mu \mathrm{m} \mathrm{SiC}$ papers; the study of thicknesses distribution shows an intermediate situation between the abraded and the mirror-like specimens; the rolling process both created a nearly mirror-like surface, increased the cold hardening (i.e., lattice defects) and reduced the grain size of the bulk; the combination of these three aspect contributes to the formation of a compact scale.

Acknowledgements The steel has been kindly provided by A. P. Steel Srl (Genova, Italy). The research leading to these results has received funding from the European Union's Seventh Framework Programme (FP7/2007-2013) Fuel Cells and Hydrogen Joint Undertaking (FCH-JU-2013-1) under Grant Agreement No. 621207.

\section{References}

[1] V. Miguel-Pérez, A. Martínez-Amesti, M.L. Nó, A. Larrañaga, M.I. Arriortua, Corros. Sci. 60, 38-49 (2012). doi:10.1016/j. corsci.2012.04.014

[2] J. Molenda, K. Swierczek, W. Zając, J. Power Sources 173, 657-670 (2007). doi:10.1016/j.jpowsour.2007.05.085

[3] Z. Shao, W. Zhou, Z. Zhu, Prog. Mater Sci. 57, 804-874 (2012). doi:10.1016/j.pmatsci.2011.08.002

[4] J. Wu, X. Liu, J. Mater. Sci. Technol. 26, 293-305 (2010). doi:10.1016/S1005-0302(10)60049-7

[5] L. Niewolak, F. Tietz, W.J. Quadakkers, in High-Temperature Solid Oxide Fuel Cells for the 21st Century (Second Edition) Fundamentals, Design and Applications, ed. by K. Kendall, M. Kendall (Elsevier, Amsterdam, 2016), pp. 195-254

[6] P. Ravi Chandran, T.V. Arjunan, Int. J. Chem. Technol. Res. 7, 488-497 (2015)

[7] S. Choi, S. Yoo, J. Kim, S. Park, A. Jun, S. Sengodan, J. Kim, J. Shin, H.Y. Jeong, Y. Choi, G. Kim, M. Liu, Sci. Rep. (2013). doi:10.1038/srep02426

[8] N. Mahato, A. Banerjee, A. Gupta, S. Omar, K. Balani, Prog. Mater Sci. 72, 141-337 (2015). doi:10.1016/j.pmatsci.2015.01. 001

[9] X. Chen, P.Y. Hou, C.P. Jacobson, S.J. Visco, L.C. De Jonghe, Solid State Ionics 176, 425-433 (2005). doi:10.1016/j.ssi.2004. 10.004

[10] A. Safikhani, M. Esmailian, T. Tinatiseresht, G.B. Darband, Int. J. Hydrog. Energy 41, 6045-6052 (2016). doi:10.1016/j. ijhydene.2016.01.090
[11] M.C. Tucker, J. Power Sources 195, 4570-4582 (2010). doi:10. 1016/j.jpowsour.2010.02.035

[12] Z. Yang, K.S. Weil, D.M. Paxton, J.W. Stevenson, J. Electrochem. Soc. 150, A1188-A1201 (2003). doi:10.1149/1. 1595659

[13] P. Piccardo, R. Amendola, in Proceedings of the International Workshop Advances and Innovations in SOFCs, Katarino, Bulgaria, 13-16 September 2009, ed. by D. Vladikova, Z. Stoynov (UCTM Printing House, Sofia, 2009), pp. 189-194

[14] C. Key, J. Eziashi, J. Froitzheim, R. Amendola, R. Smith, P. Gannon, J. Electrochem. Soc. 161, C373-C381 (2014). doi:10. $1149 / 2.0041409$ jes

[15] V.B. Trindade, U. Krupp, B.Z. Hanjari, S. Yang, H.J. Christ, Mater. Res. (Sao Carlos, Braz.) 8, 371-375 (2005)

[16] S.P. Jiang, X. Chen, Int. J. Hydrog. Energy 39, 505-531 (2014). doi:10.1016/j.ijhydene.2013.10.042

[17] W. Acchar, L.S. Barreto, H.R. Paes Junior, C.R. Cruz, E. Etzberger Feistauer, Mater. Res. (Sao Carlos, Braz.) 15, 1064-1069 (2012). doi:10.1590/S1516-14392012005000140

[18] I. Belogolovsky, P.Y. Hou, C.P. Jacobson, S.J. Visco, J. Power Sources 182, 259-264 (2008). doi:10.1016/j.jpowsour.2008.03. 080

[19] J.W. Fergus, Int. J. Hydrog. Energy 32, 3664-3671 (2007). doi:10.1016/j.ijhydene.2006.08.005

[20] M. Seabaugh, S. Ibanez, M. Beachy, M. Day, L. Thrun, ECS Trans. 35, 2471-2480 (2011). doi:10.1149/1.3570245

[21] N.J. Magdefrau, L. Chen, E.Y. Sun, M. Aindow, J. Power Sources 241, 756-767 (2013). doi:10.1016/j.jpowsour.2013.03. 181

[22] N. Shaigan, W. Qu, D.G. Ivey, W. Chen, J. Power Sources 195, 1529-1542 (2010). doi:10.1016/j.jpowsour.2009.09.069

[23] S. Elangovan, S. Balagopal, M. Timper, I. Bay, D. Larsen, J. Hartvigsen, J. Mater. Eng. Perform. 13, 265-273 (2004). doi:10. $1361 / 10599490419153$

[24] H.S. Seo, G. Jin, J.H. Jun, D.H. Kim, K.Y. Kim, J. Power Sources 178, 1-8 (2008). doi:10.1016/j.jpowsour.2007.12.026

[25] L. Cooper, S. Benhaddad, A. Wood, D.G. Ivey, J. Power Sources 184, 220-228 (2008). doi:10.1016/j.jpowsour.2008.06.010

[26] R.K.S. Raman, A.S. Khanna, R.K. Tiwari, J.B. Gnanamoorthy, Oxid. Met. 37, 1-12 (1992). doi:10.1007/BF00725848

[27] H.J. Grabke, E.M. Muller-Lorenz, S. Strauss, E. Pippel, J. Woltersdorf, Oxid. Met. 50, 241-254 (1998). doi:10.1023/A: 1018888321213

[28] Z.G. Zhang, P.Y. Hou, F. Gesmundo, Y. Niu, Appl. Surf. Sci. 253, 881-888 (2006). doi:10.1016/j.apsusc.2006.01.027

[29] H.J. Grabke, E.M. Muller-Lorenz, B. Eltester, M. Lucas, D. Monceau, Steel Res. 68, 179-185 (1997)

[30] F.H. Stott, P.K.N. Bartlett, G.C. Wood, Oxid. Met. 27, 37-55 (1987). doi:10.1007/BF00656728

[31] J. Stringer, B.A. Wilcox, R.I. Jaffee, Oxid. Met. 5, 11-47 (1972). doi:10.1007/BF00614617

[32] P. Taylor, R.J. McEachern, D.C. Doern, D.D. Wood, J. Nucl. Mater. 256, 213-217 (1998). doi:10.1016/S00223115(98)00063-4

[33] P. Piccardo, S. Anelli, V. Bongiorno, R. Spotorno, L. Repetto, P. Girardon, Int. J. Hydrog. Energy 40, 3726-3738 (2015). doi:10. 1016/j.ijhydene.2015.01.083

[34] P. Piccardo, A. Pecunia, V. Bongiorno, R. Spotorno, Z. Wuillemin, J.P. Ouweltjes, ECS Trans. 68, 2611-2624 (2015). doi: $10.1149 / 06801.2611$ ecst

[35] http://www.acciaiterni.it/pubblicazioni/444_2011.pdf. Accessed 23 Sept 2015

[36] J.H. Potgieter, F.V. Adams, N. Maledi, J. Van Der Merwe, P.A. Olubambi, J. Chem. Mater. Sci. 2, 37-48 (2012)

[37] Y. Kato, M. Ito, Y. Kato, O. Furukimi, Mater. Trans. 51, 1531-1535 (2010). doi:10.2320/matertrans.M2010112 
[38] J.L. Cavazos, Mater. Charact. 56, 96-101 (2006). doi:10.1016/j. matchar.2005.05.006

[39] H. Yan, H. Bi, X. Li, Z. Xu, Mater. Charact. 59, 1741-1746 (2008). doi:10.1016/j.matchar.2008.03.018

[40] K.F. McCarty, D.R. Boheme, J. Solid State Chem. 79, 19-27 (1989). doi:10.1016/0022-4596(89)90245-4

[41] D.J. Gardiner, C.J. Littleton, K.M. Thomas, K.N. Stratford, Oxid. Met. 27, 57-72 (1987). doi:10.1007/BF00656729

[42] P.Y. Hou, J. Ager, J. Mougin, A. Galerie, Oxid. Met. 75, 229-245 (2011). doi:10.1007/s11085-011-9235-9

[43] A. Srisrual, S. Coindeau, A. Galerie, J.P. Petit, Y. Wouters, Corros. Sci. 51, 562-568 (2009). doi:10.1016/j.corsci.2008.12. 002

[44] J. Mougin, N. Rosman, G. Lucazeau, A. Galerie, J. Raman Spectrosc. 32, 739-744 (2001). doi:10.1002/jrs.734

[45] B.D. Hosterman, Raman Spectroscopic Study of Solid Solution Spinel Oxides, Ph.D. Thesis, University of Nevada, 2011. http:// digitalscholarship.unlv.edu/thesesdissertations/1087. Accessed September 2015

[46] C. Ostwald, H.J. Grabke, Corros. Sci. 46, 1113-1127 (2004). doi:10.1016/j.corsci.2003.09.004

[47] L. Niewolak, E. Wessel, L. Singheiser, W.J. Quadakkers, J. Power Sources 195, 7600-7608 (2010). doi:10.1016/j.jpowsour. 2010.06.007

[48] Z. Yang, M.S. Walker, P. Singh, J.W. Stevenson, T. Norby, J. Electrochem. Soc. 151, B669-B678 (2004). doi:10.1149/1. 1810393

[49] P. Jian, L. Jian, H. Bing, G. Xie, J. Power Sources 158, 354-360 (2006). doi:10.1016/j.jpowsour.2005.09.056

[50] S. Geng, J. Zhu, J. Power Sources 160, 1009-1016 (2006). doi:10.1016/j.jpowsour.2006.02.028

[51] I. Saeki, H. Konno, R. Furuichi, Corros. Sci. 38, 1595-1612 (1996). doi:10.1016/0010-938X(96)00054-6

[52] B. Hua, Y. Kong, W. Zhang, J. Pu, B. Chi, L. Jian, J. Power Sources 196, 7627-7638 (2011). doi:10.1016/j.jpowsour.2011. 05.007

[53] R.E. Lobnig, H.P. Schmidt, K. Hennesen, H.J. Grabke, Oxid. Met. 37, 81-93 (1992). doi:10.1007/BF00665632
[54] Z. Yang, J.S. Hardy, M.S. Walker, G. Xia, S.P. Simner, J.W. Stevenson, J. Electrochem. Soc. 151, A1825-A1831 (2004). doi:10.1149/1.1797031

[55] S. Fontana, R. Amendola, S. Chevalier, P. Piccardo, G. Caboche, M. Viviani, R. Molins, M. Sennour, J. Power Sources 171, 652-662 (2007). doi:10.1016/j.jpowsour.2007.06.255

[56] Z. Yang, G.G. Xia, X.H. Li, J.W. Stevenson, Int. J. Hydrog. Energy 32, 3648-3654 (2007). doi:10.1016/j.ijhydene.2006.08. 048

[57] G.R. Holcomb, D.E. Alman, Scr. Mater. 54, 1821-1825 (2006). doi:10.1016/j.scriptamat.2006.01.026

[58] G.R. Holcomb, Oxid. Met. 69, 163-180 (2008). doi:10.1007/ s11085-008-9091-4

[59] M. Stanislowski, J. Froitzheim, L. Niewolak, W.J. Quadakkers, K. Hilpert, T. Markus, L. Singheiser, J. Power Sources 164, 578-589 (2007). doi:10.1016/j.jpowsour.2006.08.013

[60] S. Chandra-Ambhorn, Y. Wouters, L. Antoni, F. Toscan, A. Galerie, J. Power Sources 171, 688-695 (2007). doi:10.1016/j. jpowsour.2007.06.058

[61] J. Froitzheim, G.H. Meier, L. Niewolak, P.J. Ennis, H. Hattendorf, L. Singheiser, W.J. Quadakkers, J. Power Sources 178, 163-173 (2008). doi:10.1016/j.jpowsour.2007.12.028

[62] J.C.W. Mah, A. Muchtar, M.R. Somalu, M.J. Ghazali, Int. J. Hydrog. Energy (2016). doi:10.1016/j.ijhydene.2016.03.195

[63] X. Sun, W.N. Liu, E. Stephens, M.A. Khaleel, J. Power Sources 176, 167-174 (2008). doi:10.1016/j.jpowsour.2007.10.027

[64] A. Galerie, F. Toscan, M. Dupeux, J. Mougin, G. Lucazeau, C. Valot, A.M. Huntz, L. Antoni, Mater. Res. 7, 81-88 (2004). doi:10.1590/S1516-14392004000100012

[65] J. Mougin, M. Dupeux, L. Antoni, A. Galerie, Mater. Sci. Eng. 359, 44-51 (2003). doi:10.1016/S0921-5093(03)00355-1

[66] M. Schutze, in Failure of oxide scales on advanced materials due to the presence of stresses, ed. by Y. Saito, B. Onay, T. Maruyama (Elsevier Sci. Pub, Amsterdam, 1992), pp. 39-49

[67] W. Nicodemi, Acciai e leghe non ferrose (Zanichelli, Bologna, 2000), pp. 106-142 